7. Reprod. Fert. (1970) 23, 237-241

\title{
INFLUENCE OF THE GENOTYPE OF MALES ON PREGNANCY-BLOCK IN INBRED MICE
}

\author{
BARBARA GODOWICZ \\ Department of Animal Genetics, Jagiellonian University, \\ Kraków, Poland
}

(Received 29th October 1969)

Summary. Variations in the incidence of pregnancy-block (Bruce effect) dependent on the genotype of the male were recorded in female mice belonging to two inbred strains.

CBA females invariably responded with a high rate of return of oestrus irrespective of the blocking agent, $\mathrm{KE}$ and CBA males, or spayed and masculinized females belonging to these two strains.

By contrast, $\mathrm{KE}$ females only react strongly to $\mathrm{CBA}$ males and masculinized CBA females. Their response to males of their own strain is insignificant.

\section{INTRODUCTION}

Bruce $(1959,1960)$ described the blocking of implantation in outbred albino mice induced by the presence of an alien male, i.e. one belonging to a different strain from the stud male. The block and return of vaginal cornification are caused by a failure of luteotrophic secretion of the anterior pituitary (Parkes, 1961). The block can be prevented by the injection of reserpine, exogenous progesterone or prolactin (Dominic, 1966, 1967). The smell of alien male urine and the androgen metabolites contained in it are the cause of pregnancy failure (Dominic, 1964). A similar effect to that of alien males is produced by spayed and masculinized females (Dominic, 1965).

The sensitivity of the females to stimulation by males is genetically conditioned (Godowicz, 1967). Among four inbred strains examined, KE, KP, CBA and $\mathrm{C}_{57}, \mathrm{CBA}$ appeared to be the most sensitive (76.6\% pregnancies blocked), while this phenomenon did not occur at all in the KP strain. Moreover, the response of the CBA females to males from the different inbred strains varied with the strain (Godowicz, 1968). This could probably be ascribed to differences in pheromonal activity present in the urine of males belonging to different genotypes.

Using inbred CBA mice and two randomly mated strains, Parkes \& Bruce (1961) found that the induction of pregnancy block is determined by the relationship between the two males, and the difference between them perceived by the females irrespective of the strain to which they belong.

The object of the present study was to check the universality of this thesis 
using females of two inbred strains, $\mathrm{CBA}$ and $\mathrm{KE}$; females of the latter strain are known to possess little sensitivity to the Whitten effect, i.e. oestrous synchronization by males (Krzanowska, 1964). The introduction of spayed and masculinized females, not differing genetically from the blocking males, gave information about the extent to which differences in the hormonal levels of the males were responsible for the differences in the incidence of pregnancy-block.

\section{MATERIALS AND METHODS}

Mice of two inbred strains, KE (Krzanowska, 1965) and CBA/Kw, were used.

After the vaginal plug was found, the females were removed from the stud male and placed in a separate cage for $24 \mathrm{hr}$. Females of the experimental groups were then transferred for 5 days to a cage containing an alien male, a strange male from the same strain as the stud male, or a spayed and masculinized female of either strain. Control females were returned to their stud males after a 24-hr stay in separate cages.

The occurrence of pregnancy-block was diagnosed by vaginal smears taken for 5 days, i.e. up to Day 7 post coitum. A return of vaginal cornification within this time was regarded as a sign of blocked pregnancy.

The spayed females received a daily injection of $0.5 \mathrm{mg}$ testosterone propionate each.

\section{RESULTS}

\section{$C B A$ females (Text-fig. 1)}

CBA females mated with CBA males were exposed to KE males, or, after mating with $\mathrm{KE}$ males, were exposed to CBA males (Table 1). In both situations, a high proportion of pregnancies was blocked. The differences between them were not significant.

Exposure of CBA females to masculinized CBA and KE females also induced a high proportion of blocked pregnancies. The difference between them was not significant.

Using the independence test, the percentage of pregnancy failure in CBA females exposed to masculinized $\mathrm{KE}$ females was found to be higher than that of females exposed to $\mathrm{KE}$ males $\left(\chi^{2}=4.27, P<0.05\right)$, but the difference observed between the alien CBA male and the masculinized CBA female was not significant.

In the control group, the return of the females to the stud male did not induce the return of vaginal cornification, but exposure to a strange male brought about some blocked pregnancies, the strange $\mathrm{KE}$ male evoking, indeed, a stronger reaction than the strange CBA male $\left(\chi^{2}=5.63, P<0.02\right)$.

KE females (Text-fig. 2)

Females of this strain manifest a tendency to vaginal cornification (Godowicz, 1967) which makes the results more difficult to analyse.

Oestrus returned in $13.3 \%$ of control females mated with KE males, but there was no reaction when the stud male belonged to the CBA strain. 


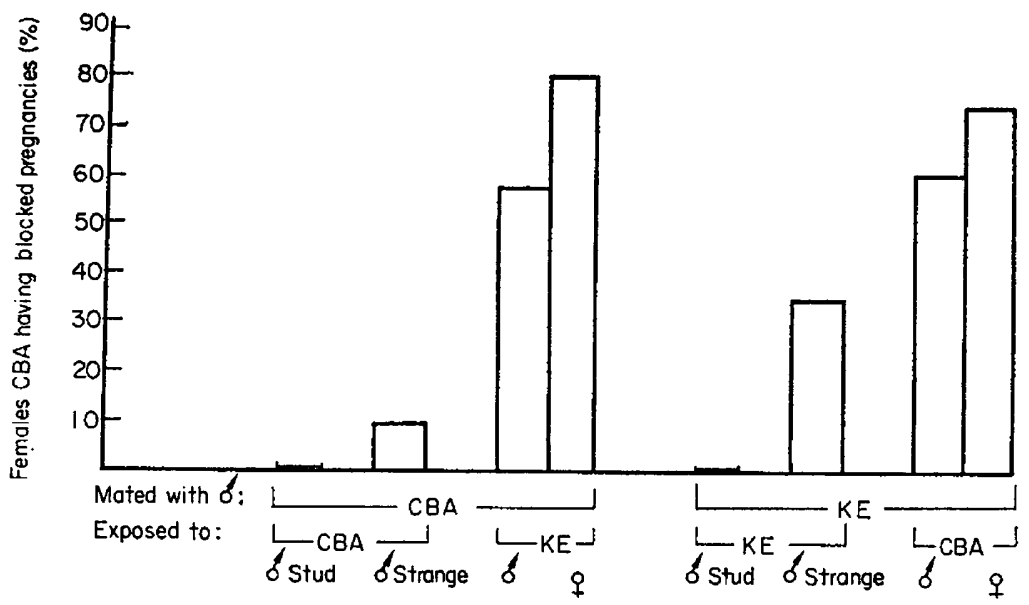

TEXT-FIo. 1. Percentage of pregnancy-block in various experimental designs.

KE females mated with KE males and exposed to CBA males responded with a high proportion of blocked pregnancies $(63.1 \%)$; but in the reverse situation (mated with CBA male, exposed to KE male), only $12 \%$ of pregnancy failures were recorded. Exposure of KE females to a strange male gave results similar to those for females returned to their stud males, i.e. a small percentage of pregnancies blocked by KE males and a complete absence of response to GBA males.

Pregnancy was blocked to a small extent by exposure of the KE females to masculinized females of either strain and there was no significant difference

TABLE 1

PROPORTION OF THE FEMALES RETURNING TO OESTRUS IN VARIOUS EXPERIMENTAL DESIGNS

\begin{tabular}{|c|c|c|c|c|}
\hline $\begin{array}{l}\text { Genotype } \\
\text { of females } \\
\text { tested }\end{array}$ & $\begin{array}{l}\text { Genotype } \\
\text { of stud } \\
\text { male }\end{array}$ & \multicolumn{2}{|c|}{$\begin{array}{c}\text { Genotype } \\
\text { of blocking } \\
\text { male or female }\end{array}$} & $\begin{array}{c}\text { Proportion of } \\
\text { females returning } \\
\text { to oestrus }\end{array}$ \\
\hline $\begin{array}{l}\text { CBA } \\
\text { CBA } \\
\text { CBA } \\
\text { CBA } \\
\text { CBA } \\
\text { CBA } \\
\text { CBA } \\
\text { GBA }\end{array}$ & $\begin{array}{l}\text { CBA } \\
\text { CBA } \\
\text { CBA } \\
\text { CBA } \\
\text { KE } \\
\text { KE } \\
\text { KE } \\
\text { KE }\end{array}$ & 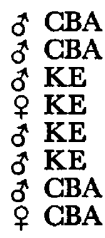 & $\begin{array}{l}\text { stud } \\
\text { strange } \\
\text { alien } \\
\text { alien } \\
\text { stud } \\
\text { strange } \\
\text { alien } \\
\text { alien }\end{array}$ & $\begin{array}{r}0 / 20 \\
2 / 21 \\
12 / 21 \\
17 / 21 \\
0 / 20 \\
10 / 29 \\
12 / 20 \\
14 / 19\end{array}$ \\
\hline $\begin{array}{l}\mathrm{KE} \\
\mathrm{KE} \\
\mathrm{KE} \\
\mathrm{KE} \\
\mathrm{KE} \\
\mathrm{KE} \\
\mathrm{KE} \\
\mathrm{KE}\end{array}$ & $\begin{array}{l}\mathrm{KE} \\
\mathrm{KE} \\
\mathrm{KE} \\
\mathrm{KE} \\
\mathrm{CBA} \\
\mathrm{CBA} \\
\mathrm{CBA} \\
\mathrm{CBA}\end{array}$ & $\begin{array}{l}\text { o } \mathrm{KE} \\
\text { o } \mathrm{KE} \\
\text { ot } \mathrm{CBA} \\
\text { o } \mathrm{GBA} \\
\text { o } \mathrm{GBA} \\
\text { o } \mathrm{GBA} \\
\text { ot } \mathrm{KE} \\
\text { o } \mathrm{KE}\end{array}$ & $\begin{array}{l}\text { stud } \\
\text { strange } \\
\text { alien } \\
\text { alien } \\
\text { stud } \\
\text { strange } \\
\text { alien } \\
\text { alien }\end{array}$ & $\begin{array}{r}4 / 30 \\
3 / 21 \\
12 / 19 \\
10 / 24 \\
0 / 25 \\
0 / 27 \\
3 / 25 \\
6 / 23\end{array}$ \\
\hline
\end{tabular}


between the strains (Table 1). The response to masculinized $\mathrm{KE}$ females was slightly higher than to $\mathrm{KE}$ males, but the difference was also not significant.

There was no significant difference between the proportions of pregnancies blocked by alien CBA males or masculinized CBA females; in both cases, there there was a strong reaction.

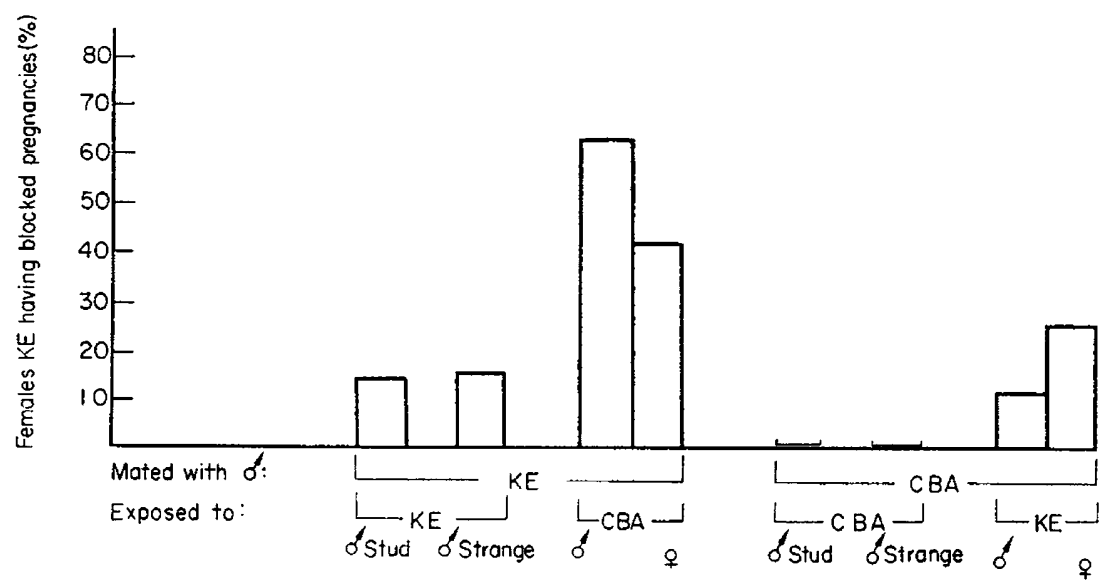

TExT-FIG. 2. Percentage of pregnancy-block in various experimental designs.

\section{DISCUSSION}

The occurrence of pregnancy-block is closely related to hormonal activity both in the female, in which the failure of pregnancy occurs, and in the male which evokes this disturbance. The inbred females differ in their hormonal level and therefore they vary in their reaction to environmental stimuli received during the early stages of pregnancy. Wild mice are clearly more sensitive to changes of environment than most laboratory strains and their levels of ACTH secretion in response to such changes are probably higher. An adequate level of ACTH can inhibit the secretion of gonadotrophin (Snyder \& Taggart, 1967).

It has been shown (Godowicz, 1968) that CBA females which demonstrate a high sensitivity to stimulation by males, respond with a varying percentage of blocked pregnancies to exposure to males of different genotypes. Both KE and CBA males provide a strong stimulus, no matter which of them is the stud male and which the alien male. This was shown by the absence of a significant difference in response when the CBA female was mated with a $\mathrm{KE}$ male and her pregnancy blocked by a CBA male, and vice versa.

However, one should not generalize from this phenomenon since $\mathrm{KE}$ females, unlike the CBA females, demonstrated a strong reaction only to the presence of a blocking CBA male. In the reverse situation, the response to the alien KE male was negligible. It can, therefore, be concluded that an interaction takes place here between the genotype of the male and that of the female, which is mutually weak when both partners belong to the KE strain. Both sexes of this strain are capable of a full reaction with partners from different strains. The same situation also applies to the synchronization of oestrus by the male (Krzanowska, 1964). 
Comparison of the incidence of blocked pregnancies induced by males and by masculinized females showed no differences in respect of the CBA strain but, in the KE strain, masculinized females of both strains provided stronger stimuli than males. The higher percentage of pregnancy blocks caused by the masculinized females can be explained by the very large dose of testosterone propionate which they received. Hence, it can be supposed that the urine of KE males does not contain a sufficient amount of the appropriate pheromones. This, in turn, is probably connected with a hormonal deficiency in these males.

\section{REFERENCES}

Bruce, H. M. (1959) An exteroceptive block to pregnancy in the mouse. Nature, Lond. 184, 105.

BRUCE, H. M. (1960) Further observations on pregnancy block in mice caused by proximity of strange males. J. Reprod. Fert. 1, 311.

Dominic, C. J. (1964) Source of the male odour causing pregnancy block in mice. F. Reprod. Fert. 8, 266.

Dominic, C. J. (1965) The origin of the pheromones causing pregnancy block in mice. F. Reprod. Fert. $10,469$.

Dominic, C. J. (1966) Observations on the reproductive pheromones of mice. F. Reprod. Fert. 11, 415.

Dominic, C. J. (1967) Effect of exogenous prolactin on olfactory block to pregnancy in mice exposed to urine of alien males. Indian Jnl exp. Biol. 5, 47.

Godowicz, B. (1967) Pregnancy block in inbred mice and in the $F_{1}$ crosses. Folia biol., Krakow, 15, 217.

Godowicz, B. (1968) Pregnancy block in inbred mice and in the $F_{1}$ crosses. Part II. Folia biol., Krakow, 16, 199.

KrzanowsKa, H. (1964) Studies on heterosis. III. The course of the sexual cycle and the establishment of pregnancy in mice, as affected by the type of mating. Folia biol., Kraców, 12, 415.

Krzanowska, H. (1965) New inbred strains of mice. Mouse News Lett. 32, 54.

PARkes, A. S. (1961) An olfactory block to pregnancy in mice. II. Hormonal factors involved. Proc. IVth Int. Congr. Anim. Reprod., The Hague, pp. 163.

PARkes, A. S. \& BRUCE, H. M. (1961) Olfactory stimuli in mammalian reproduction. Science, N.Y. 134, 1049.

SNYDER, R. L. \& TAGGART, N. E. (1967) Effects of adrenalectomy on male-induced pregnancy block in mice. F. Reprod. Fert. 14, 451. 